\title{
Value and Cost of Farm-Mixed Rations Used in Swine-Feeding Trials at Lajas Substation
}

\author{
Ismael Carlo ${ }^{1}$
}

\section{INTRODUCTION}

Many farmers are at present interested in the swine industry. The main limitation to the expansion of this industry is the cost of feed concentrates. There is need for information on the cost of producing a market animal, the quantity of feed needed, and the income to be expected from the enterprise. This paper was prepared to provide information on swine feeding, suitable rations, and the ingredients that can be utilized to greater advantage in the preparation of these rations.

\section{MATERIALS AND METHODS}

Some years ago this Experiment Station started mixing its own swine feed, using imported ingredients together with others of local origin. The aim was to produce a cheap but well-balanced ration for its own herd and to offer the pig-raiser of the Island the information thus gathered.

This study covered periods from October 1953 to July 1955. The data on three consecutive feeding trials have been used for this paper. The period extended from weaning at 56 days to 154 days of age in each feeding trial. Computation of the feed used and net gain of the pigs was thus based on 98-days periods. Only gilts and barrows were considered. The animals were fed individually.

The feed given was prepared at the Station's mixing unit. The pigs were fed ad libitum from self-feeders provided in the individual pens. About 45 square feet of concrete floor space was allowed to each pig. Clean water was provided at all times. The animals were weighed every 14 days and the feed consumption recorded accordingly.

\section{RESULTS}

A total of 222 pigs, 154 gilts and 68 barrows were included. The average net gain in weight was found to be 147 pounds and the average amount of feed consumed to attain this gain was found to be 595 pounds. To get the

${ }^{1}$ Assistant Animal Husbandman, Lajas Agricultural Substation, Agricultural Experiment Station, Río Piedras, P. R. The author wishes to express his appreciation to Antonio González Chapel and to Luis Rivera Brenes, Assistant Director, and Head of the Department of Animal Husbandry, respectively, of Agricultural Experiment Station, for their assistance in the preparation of this manuscript. 
TABLE 1.-Composition (pounds) of ration I used in swine-feeding trials

\begin{tabular}{l|r|r|r|r|r}
\hline \multicolumn{1}{c|}{ Ingredient } & Quantity & $\begin{array}{c}\text { Total crude } \\
\text { protein }\end{array}$ & $\begin{array}{c}\text { Total } \\
\text { crude fat }\end{array}$ & $\begin{array}{c}\text { Total crude } \\
\text { fiber }\end{array}$ & Total NFE \\
\cline { 2 - 4 } & 230 & 73.60 & 5.75 & 14.95 & 69.00 \\
Hog concentrate, 32-percent & 120 & 17.40 & 3.60 & 12.00 & 60.00 \\
Wheat bran & 100 & 12.00 & 4.70 & 10.60 & 60.20 \\
Pulverized oats & 100 & - & - & - & 61.90 \\
Cane molasses & 450 & 42.30 & 15.75 & 13.50 & 292.50 \\
Yellow corn No. 2 & 1,000 & 145.30 & 29.80 & 51.05 & 543.60 \\
Total & &
\end{tabular}

TABLE 2.-Comparative net returns for market hogs grown on feed costing $\$ 8.00$ to $\$ 3.50$ per $100 \mathrm{lb} .1$

\begin{tabular}{|c|c|c|c|c|c|c|c|c|c|}
\hline \multirow{2}{*}{$\begin{array}{l}\text { Feed cost } \\
\text { per } 100 \mathrm{lb} \text {. }\end{array}$} & \multirow{2}{*}{$\begin{array}{l}\text { Feed cost } \\
\text { to produce } \\
147 \mathrm{lb} \text {. of } \\
\text { gain }\end{array}$} & \multirow{2}{*}{$\begin{array}{l}\text { Other } \\
\text { costs } \\
\text { (estimated } \\
\text { to be } 20 \\
\text { percent of } \\
\text { total costs) }\end{array}$} & \multirow{2}{*}{$\begin{array}{c}\text { Total cost } \\
\text { to produce } \\
147 \mathrm{lb} \text { of } \\
\text { gain }\end{array}$} & \multicolumn{3}{|c|}{$\begin{array}{c}\text { Total selling price of the } \\
\text { pig at- }\end{array}$} & \multicolumn{3}{|c|}{ Net income per pig at- } \\
\hline & & & & $19 \mathrm{k} / \mathrm{lb}$ & $20 \xi / \mathrm{lb}$. & $21 \xi / \mathrm{lb}$. & $19 \xi / \mathrm{lb}$. & $20 \mathrm{k} / \mathrm{lb}$ & $21 \xi / \mathrm{lb}$. \\
\hline 3.00 & 17.85 & 4.46 & 22.31 & 27.93 & 29.40 & 30.87 & 5.62 & 7.09 & 8.56 \\
\hline 3.05 & 18.15 & 4.54 & 22.69 & 27.93 & 29.40 & 30.87 & 5.25 & 6.72 & 8.19 \\
\hline 3.10 & 18.45 & 4.61 & 23.06 & 27.93 & 29.40 & 30.87 & 4.87 & 6.35 & 7.82 \\
\hline 3.15 & 18.75 & 4.68 & 23.43 & 27.93 & 29.40 & 30.87 & 4.50 & 5.98 & 7.45 \\
\hline 3.20 & 19.04 & 4.76 & 23.80 & 27.93 & 29.40 & 30.87 & 4.13 & 5.61 & 7.08 \\
\hline 3.25 & 19.34 & 4.83 & 24.17 & 27.93 & 29.40 & 30.87 & 3.76 & 5.24 & 6.71 \\
\hline $\mathbf{3 . 3 0}$ & 19.64 & 4.90 & 24.54 & 27.93 & 29.40 & 30.87 & 3.39 & 4.87 & 6.34 \\
\hline 3.35 & 19.93 & 4.98 & 24.91 & 27.93 & 29.40 & 30.87 & 3.02 & 4.50 & 5.97 \\
\hline 3.40 & 20.23 & 5.05 & 25.28 & 27.93 & 29.40 & 30.87 & 2.65 & 4.13 & 5.60 \\
\hline 3.45 & 20.52 & 5.13 & 25.65 & 27.93 & 29.40 & 30.87 & 2.28 & 3.76 & 5.23 \\
\hline 3.50 & 20.82 & 5.20 & 26.02 & 27.93 & 29.40 & 30.87 & 1.91 & 3.39 & 4.86 \\
\hline
\end{tabular}

1 The average of $147 \mathrm{lb}$. of gain were made by 154 gilts and 68 barrows in a period which covered 3 feeding trials from October 1953 to July 1955. To attain this gain animals consumed $595 \mathrm{lb}$. of feed and needed $404 \mathrm{lb}$. of feed per $100 \mathrm{lb}$. of gain.

TABLE 3.-Composition (pounds) of ration 2 used in swine-feeding trials

\begin{tabular}{l|r|r|r|r|r}
\hline \multicolumn{1}{c|}{ Ingredients } & Quantity & $\begin{array}{c}\text { Total crude } \\
\text { protein }\end{array}$ & $\begin{array}{r}\text { Total crude } \\
\text { fat }\end{array}$ & $\begin{array}{r}\text { Total crude } \\
\text { fiber }\end{array}$ & Total NFE \\
\hline Yellow corn No. 2 & 425 & 36.13 & 16.15 & 10.63 & 293.25 \\
Soybean-oil meal & 100 & 44.00 & .50 & 6.00 & 31.00 \\
Cane molasses & 130 & - & - & - & 80.60 \\
Corn-gluten feed & 50 & 10.50 & 1.00 & 4.50 & 24.50 \\
Dried brewer's grains & 100 & 26.00 & 6.00 & 15.00 & 42.00 \\
Wheat gray shorts & 100 & 16.00 & 4.50 & 6.00 & 55.00 \\
Royal palm seeds & 70 & 4.27 & 5.81 & 15.96 & 30.66 \\
Tankage & 25 & 12.58 & 1.50 & .63 & .63 \\
Total & 1,000 & 149.48 & 35.46 & 58.72 & 557.64 \\
\hline
\end{tabular}


total weight of the live pig the weaning weight should be thus added. The composition of ration 1 used in the trials described here is shown in table 1.

The proximate analysis of this ration is $\mathbf{1 4 . 5}$ percent of crude protein, 3 of crude fat, 5.1 of crude fiber, and 54.4 percent of nitrogen-free extract.

Table 2 gives the comparative net returns for market hogs making 147 pounds of net gain after weaning, when consuming 595 pounds of feed, and assuming that the cost of the feed is 80 percent of the total cost of production as found in this Station, and given prices of feed and hogs on the hoof.

This Station has formulated and used other rations with similar nutritional values, but cheaper to make, such as the two presented in tables 3 and 4 . The proximate analysis of the ration shown in table 3 is approximately 15.4 percent of crude protein, 3.5 of crude fat, 5.9 of crude fiber,

TABLE 4.-Composition (pounds) of ration 8 used in swine-feeding trials

\begin{tabular}{l|r|r|r|r|r}
\hline \multicolumn{1}{c|}{ Ingredients } & Quantity & $\begin{array}{c}\text { Total crude } \\
\text { protein }\end{array}$ & $\begin{array}{r}\text { Total crude } \\
\text { fat }\end{array}$ & $\begin{array}{r}\text { Total crude } \\
\text { fiber }\end{array}$ & Total NFE \\
\cline { 2 - 5 } & 450 & 42.30 & 15.75 & 13.50 & 292.50 \\
Yellow corn No. 2 & 100 & 40.00 & 3.00 & 9.00 & 27.00 \\
Hog concentrate, 40-percent & 50 & 8.00 & 1.75 & 3.00 & 27.50 \\
Wheat gray shorts & 50 & 13.00 & 2.50 & 9.00 & 20.00 \\
Dried brewer's grains & 125 & - & - & - & 77.38 \\
Cane molasses & 70 & 4.27 & 5.81 & 15.96 & 30.66 \\
Royal palm seed & 60 & 7.20 & 1.80 & 7.80 & 36.12 \\
Pulverized oats & 45 & 9.45 & .90 & 4.05 & 19.35 \\
Corn-gluten feed & 50 & 22.00 & .25 & 2.75 & 15.15 \\
Soybean oil meal & 1,000 & 146.22 & 31.76 & 65.06 & 545.66 \\
\hline
\end{tabular}

and 55.8 of nitrogen-free extract. The proximate analysis of the ration shown in table 4 is 14.6 percent of crude protein, 3.2 of crude fat, 6.5 of crude fiber, and 54.6 of nitrogen-free extract.

\section{DISCUSSION}

Special attention should be given to having adequate amounts of the constituents in the ration. Some ingredients are high in protein but are also high in fiber. Growing fattening pigs should not receive more than 6 percent of crude fiber in the ration. Ingredients high in fiber tend to be laxative. Molasses, used in liberal amounts, is laxative; 10 to 13 percent in the ration is safe. All cereals are low in calcium and therefore rations in which cereals are used liberally should be supplemented with minerals. Other ingredients, like royal palm seed and rice bran, are high in fat, and should be limited in their use because they have a tendency to produce too much fat. We have used around 10 percent in the ration successfully. 
All the ingredients used in these rations may be imported from Continental United States and are available almost throughout the year.

Some ingredients such as these can be obtained locally: Cane molasses, royal palm nuts, and, in the near future, soybean-oil meal will also be available. To reduce the costs ingredients should be bought by the carload directly from the mills. Farmers using over 400 bags a month are in the best position to mix on the farm. Smaller farmers have to work cooperatively with others to get the advantages of this system.

An analysis of table 2 shows that feed cost is of primary importance in the growing and fattening of swine. One way of lowering the cost of swine feeds to an economical basis is to mix them on the farm.

Based on average prices of the ingredients for the year 1956-57, the cost of ration 1 was around $\$ 3.78$ per hundredweight; ration $2, \$ 3.49$; and ration 3 , \$3.38 per hundredweight. Costs, of course, vary according to the variations in price of the different ingredients. When some of these ingredients, like soybean meal, become available locally, costs will probably be lower. Direct shipments also reduces the costs.

\section{SUMMARY}

Data gathered at the Lajas Substation from October 1953 to July 1955, using 222 pigs in individual feeding trials, showed that feed can be mixed at the farm with economic advantage to the farmer. There are some locally produced ingredients which can be used in the rations. Among them are molasses and royal palm nuts. Probably some others could be secured in the near future. Other ingredients still could be bought from Continental United States. Small farmers can work cooperatively in order to take advantage of the system. The rations used and their approximate costs are given in this paper.

\section{RESUMEN}

Según datos obtenidos en la Subestación Experimental Agrícola de Lajas, es ventajoso mezclar alimentos para cerdos en la propia finca. El alimento así obtenido resulta más barato $\mathrm{y}$, por lo tanto, el beneficio neto por cerdo es mayor. Hay algunos ingredientes que se pueden conseguir localmente como la miel de caña y la semilla de la palma real. En un futuro cercano es posible que se puedan obtener localmente otros ingredientes. Los que ahora no se consiguen en plaza podrían importarse con relativa facilidad de Estados Unidos. Los agricultores de pocos recursos podrían trabajar en forma cooperativa para beneficiarse del sistema. En este trabajo se presentan las raciones que pueden utilizarse y su costo aproximado por quintal. 